\title{
STRATEGI DIPLOMASI EKONOMI INDONESIA DALAM MENGHADAPI PANDEMI COVID-19
}

\author{
Aloysius Anandyo Pambudi \\ Magister Ilmu Hubungan Internasional Fakultas Ilmu Sosial dan Ilmu Politik \\ Universitas Indonesia, \\ aloysius.anandyo@ui.ac.id
}

\begin{abstract}
The Covid-19 outbreak has caused a multi-sector global crisis on health, social, economic, and leadership aspects. Indonesia, as one of the Asia-Pacific countries which had significant economic growth for the last decade, is also facing a huge economic and social decline due to this pandemic. In order to face these challenges, the Indonesian government changed its economic diplomacy strategy by issued some policies regarding to upheld the national export-import performance and hold the negative economic impacts of the outbreak. This article provides a comprehensive analysis and descriptions about Indonesia's economic diplomacy strategies in facing the Covid-19 pandemic. By adopting an analytical framework of economic diplomacy, this research shows that Indonesia's government economic diplomacy strategies during the Covid-19 pandemic exist in both primary and support activities, consisting of commercial and marketing activities, business advocation, network-building, business negotiations, intelligence services, and also problem-solving mechanisms.
\end{abstract}

Keywords: Indonesia, Economic Diplomacy, Strategies, Covid-19

\section{PENDAHULUAN}

\section{Latar Belakang}

Terjadinya pandemi Severe Acute Respiratory Syndrome Coronavirus 2 (SARS-CoV-2)/ Corona Virus Disease 2019 (Covid-19) telah menyebabkan krisis kesehatan, sosial, ekonomi, dan kepemimpinan yang terjadi secara global. Berdasarkan catatan yang dihimpun dari World Health Organization (WHO), memasuki bulan Agustus 2020 pandemi Covid-19 telah merenggut 728.013 jiwa di seluruh dunia (World Health Organization, 2020). Ditinjau dari sisi ekonomi, pandemi Covid-19 diproyeksikan berdampak pada kontraksi perekonomian global sebesar minus 3 persen dan penurunan volume 
perdagangan dunia hingga minus 11 persen di penghujung tahun 2020 (International Monetary Fund, 2020b). Angka ini diproyeksikan dapat memicu resesi ekonomi global baik dalam jangka menengah maupun panjang dimulai dari kuartal 2 tahun 2020. IMF bersama dengan World Bank juga mencatat bahwa pandemi ini berpotensi berdampak pada bertambahnya jumlah masyarakat miskin dunia hingga 50 juta jiwa (International Monetary Fund, 2020b; World Bank Group, 2020).

Bagi kawasan Asia-Pasifik yang selama satu dekade terakhir mengalami tren positif pertumbuhan ekonomi yang cukup pesat, pandemi Covid-19 turut berdampak pada perlambatan rata-rata pertumbuhan ekonomi hingga minus 4 persen (International Monetary Fund, 2020b). Kondisi ini turut memicu penurunan PDB negara-negara, jatuhnya harga barang, defisit neraca berjalan, hingga meningkatnya angka pengangguran. Tidak terkecuali Indonesia, pandemi Covid-19 menyebabkan pertumbuhan ekonomi pada kuartal 1 tahun 2020 hanya berada pada angka 2,9 persen (International Monetary Fund, 2020b). Bahkan memasuki kuartal 2 tahun 2020, pertumbuhan ekonomi Indonesia tercatat berada pada angka minus 5,3 persen (Ulya, 2020). Angka ini jauh dari rata-rata pertumbuhan perekonomian Indonesia yang biasanya berada di kisaran angka 5 persen.

Menyikapi krisis kesehatan serta potensi resesi perekonomian global maupun nasional, pemerintah Indonesia telah menyiapkan anggaran sebesar 677,2 triliun rupiah yang ditujukan untuk percepatan penanganan pandemi Covid-19 serta pemulihan ekonomi nasional (International Monetary Fund, 2020a). Anggaran ini dialokasikan untuk pemberian dukungan terhadap sektor kesehatan, pemberian bantuan sosial bagi masyarakat kelas menengah ke bawah, pemberian jaminan sosial bagi masyarakat yang kehilangan pekerjaan, pelonggaran pembayaran pajak, hingga dukungan terhadap sektor industri (International Monetary Fund, 2020a). 
Salah satu elemen yang menjadi strategi perbaikan perekonomian nasional Indonesia, khususnya berkaitan dengan sektor perdagangan dan perindustrian, adalah perubahan strategi diplomasi ekonomi. Dalam hal ini, diplomasi ekonomi ditujukan untuk menopang kinerja ekspor-impor dan "menahan" dampak ekonomi sebagai imbas pandemi Covid-19. Melalui Kementerian Perdagangan, Kementerian Luar Negeri, dan Kementerian Perindustrian, pemerintah Indonesia menerapkan strategi diplomasi ekonomi dalam menghadapi pandemi Covid-19 dengan mengacu pada Peraturan Menteri Perdagangan Republik Indonesia (Permendag) No. 10 Tahun 2020, Peraturan Pemerintah Pengganti Undang-Undang (Perppu) No. 1 Tahun 2020, Keputusan Presiden (Keppres) No. 9 Tahun 2020, serta Keppres No. 11 tahun 2020 (Kontan, 2020).

Berangkat dari uraian di atas, muncul urgensi untuk mengidentifikasi dan memahami strategi serta upaya-upaya diplomasi ekonomi yang dilakukan oleh pemerintah Indonesia dalam menghadapi dampak negatif pandemi Covid-19. Beberapa ulasan terdahulu yang berkaitan dengan topik tersebut diantaranya dapat ditemukan dan diklasifikasikan dalam tiga kelompok. Pertama adalah kelompok literatur yang berfokus pada substansi dan implementasi diplomasi ekonomi Indonesia, seperti ditunjukkan dalam penelitian tentang tantangan dan peluang diplomasi ekonomi dalam masa pemerintahan Presiden Joko Widodo (Wangke, Pujayanti dan Lisbet, 2015), diplomasi ekonomi Indonesia terhadap pasar di Timur Tengah (Kurniawan, 2014), dan penguatan diplomasi ekonomi Indonesia khususnya dalam strategi clustering tujuan pasar ekspor (Sabaruddin, 2015). Selain itu, terdapat penelitian yang mengulas grand design diplomasi ekonomi Indonesia melalui pendekatan indeks diplomasi ekonomi (Sabaruddin, 2017), diplomasi ekonomi Indonesia dalam G-33 (Delanova, 2016), serta paradigma dan problematika dalam diplomasi ekonomi Indonesia (Killian, 2012). 
Kelompok kedua adalah literatur yang membahas imbas pandemi terhadap pertumbuhan ekonomi dan perdagangan Indonesia, diantaranya adalah penelitian yang dilakukan oleh Yose Rizal Damuri (Damuri dan Hirawan, 2020) dan Eka Budiyanti (Budiyanti, 2020).

Sementara itu kelompok ketiga adalah studi yang membahas seputar kebijakan Indonesia dalam penanganan pandemi Covid -19, diantaranya adalah ulasan tentang kebijakan perdagangan pangan Indonesia saat Covid-19 (Amanta dan Aprilianti, 2020), kerjasama global dalam pendekatan multijalur (Djelantik, 2020), pemanfaatan diplomasi publik oleh Indonesia dalam krisis Covid-19 (Martha, 2020), kerjasama Indonesia-Korea Selatan dalam penanganan Covid-19 (Mantong dan Kharisma, 2020), diplomasi Indonesia di ASEAN dalam merespon pandemi (Falahi dan Nainggolan, 2020), strategi pemberian stimulus (Tahir, 2020), dan fokus fondasi strategi Indonesia dalam menghadapi pandemi Covid-19 (Kembara, 2020).

Melihat studi terdahulu seperti yang telah dipaparkan di atas, tampak bahwa kajian literatur yang mengulas secara komprehensif strategi diplomasi ekonomi Indonesia dalam menghadapi pandemi Covid-19 masih minim dilakukan. Maka dari itu, dengan mengadopsi pendekatan ekonomi-politik internasional dalam kerangka konseptual diplomasi ekonomi, penelitian ini bertujuan untuk memberikan gambaran utuh tentang bentuk-bentuk diplomasi ekonomi yang dilakukan pemerintah Indonesia dalam konteks penanganan pandemi Covid-19, mengklasifikasikan aktivitas diplomasi ekonomi tersebut baik dalam kelompok aktivitas primer dan sekunder, serta menjelaskan hubungan antar aktor yang terlibat dalam upaya diplomasi ekonomi nasional.

\section{Kerangka Pemikiran}

Penelitian ini menggunakan kerangka konseptual diplomasi ekonomi untuk memberikan gambaran tentang strategi pemerintah Indonesia dalam menangani dampak negatif pandemi terhadap perekonomian nasional. Dalam 
lokus ilmu hubungan internasional, muncul berbagai literatur yang mencoba memberikan definisi tentang "diplomasi ekonomi", baik yang melihatnya sebagai fenomena dan aktivitas ekonomi-politik internasional, menjadi bagian dari praktik diplomasi (politik), maupun sebagai bagian dari aktivitas bisnis secara utuh. Hal ini menyebabkan ketiadaan definisi tunggal mengenai diplomasi ekonomi sehingga membuka ruang untuk dieksplorasi secara lebih dalam (Stadman dan Ruël, 2012).

Dalam pemahaman diplomasi ekonomi sebagai aktivitas aktor negara, Maaike Okano-Heijmans menjelaskan perbedaan dan saling keterhubungan antara diplomasi ekonomi, economic statecraft, keamanan ekonomi, diplomasi perdagangan, diplomasi komersial, dan diplomasi finansial (Okano-Heijmans, 2011). Posisi konsep-konsep tersebut digambarkan melalui matriks yang menunjukkan spektrum aktivitas politik (power-play end) hingga ekonomi (business-end). Masih dalam kerangka pemahaman yang sama, diplomasi ekonomi juga dilihat sebagai instrumen kerjasama dua arah antara pemerintah dan pelaku bisnis untuk mencapai tujuan-tujuan ekonomi (Kopp, 2004), sebagai aktivitas kebijakan perdagangan negara dan upaya internasionalisasi sektor bisnis domestik (Curzon, 1965), dan sebagai aksi yang dilakukan pemerintah untuk memfasilitasi peningkatan perdagangan (Klinkby, 2013).

Sementara itu, Olivier Naray meletakkan agenda promosi, fasilitasi, dan ekspansi aktivitas bisnis domestik ke level internasional sebagai inti dari proses diplomasi ekonomi (Kostecki dan Naray, 2007; Naray dan Bezençon, 2017). Dalam kerangka pemahaman ini, diplomasi ekonomi secara substansial dan praktis dianggap serupa dengan diplomasi komersial maupun bisnis. Secara lebih spesifik, Naray dan Kostecki mengidentifikasi dua aktivitas dalam diplomasi ekonomi. Pertama adalah primary activities, yang berkaitan dengan perdagangan dan foreign direct investments (FDIs), pengembangan riset dan teknologi, promosi pariwisata serta advokasi bisnis. Kedua adalah support 
activities, yang merupakan dukungan terhadap aktivitas primer, seperti intelijen, pembangunan jaringan, negosiasi bisnis, dan mekanisme penyelesaian permasalahan.

Diplomasi ekonomi juga dapat dipahami dalam konteks yang lebih luas, seperti terintegrasi dalam visi transformasi (ekonomi) nasional sebuah negara (Aleidan, 2019), maupun menjadi bagian dalam pembentukan "nation branding"; merujuk pada promosi terhadap reputasi kompetensi bisnis nasional (Reuvers dan Ruël, 2012).

Meskipun diplomasi ekonomi erat kaitannya dengan peran sentral aktor negara, namun Stadman dan Ruel menegaskan ketiadaan prinsip "one size fits all" dalam diplomasi ekonomi. Ia melihat bahwa diplomasi ekonomi hadir dalam berbagai variasi bentuk, menyesuaikan dengan karakteristik negara asal dan negara tujuan (Stadman dan Ruël, 2012). Hal senada juga diungkapkan oleh Susan Strange, yang menilai bahwa keberhasilan diplomasi ekonomi tidak hanya ditentukan oleh aktor negara, namun juga aktor lain khususnya private enterprises (Strange, 1992). Bahkan Yakop dan Bergeijk justru melihat bahwa diplomasi ekonomi merupakan aktivitas yang membawa keuntungan utama bagi private companies (Veenstra, Yakop dan Bergeijk, 2010).

Dalam penelitian ini, penulis menggunakan konsep diplomasi ekonomi yang dikemukakan oleh Olivier Naray dan Michel Kostecki. Konsep ini digunakan untuk mengidentifikasi dan menganalisis implementasi diplomasi ekonomi yang dilakukan oleh pemerintah Indonesia dalam menangani dampak negatif pandemi Covid-19 terhadap pertumbuhan perekonomian dan perdagangan nasional. Konsep ini digunakan karena mampu memberikan deskripsi tentang bentuk-bentuk diplomasi ekonomi, baik yang berada pada kategori primary maupun support activities, serta mengidentifikasi tujuan politik (power-play end) maupun ekonomi (business-end) dalam aktivitas diplomasi ekonomi yang dilakukan. Hal ini dapat membantu untuk 
memberikan gambaran tentang topik yang diteliti. Secara sederhana, model analisis atau alur rencana pemecahan masalah dalam penelitian ini dapat dilihat melalui bagan berikut:

\section{Bagan 1. Model Analisis Penelitian}

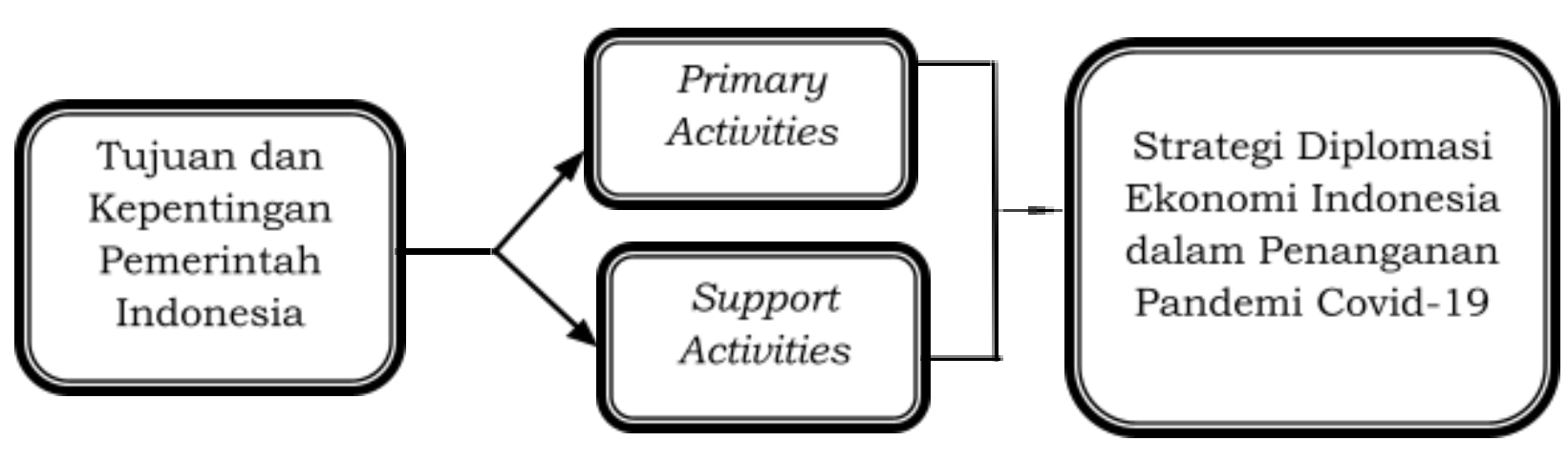

\section{PEMBAHASAN}

\section{Tinjauan Umum Diplomasi Ekonomi Indonesia}

Kerangka diplomasi ekonomi Indonesia secara rinci dijabarkan dalam Rencana Strategis Kementerian Luar Negeri Republik Indonesia periode tahun 2015-2019. Dalam dokumen tersebut, diplomasi ekonomi menjadi salah satu sasaran strategis, fokus, dan prioritas politik luar negeri Indonesia dalam menghadapi dinamika politik global serta menjadi instrumen dalam mewujudkan kemakmuran rakyat Indonesia (Kementerian Luar Negeri, 2015b). Diplomasi ekonomi dilakukan melalui strategi investasi perdagangan, peningkatan daya saing, financial inclusion, dan peningkatan produktivitas (Kementerian Luar Negeri, 2015b). Melalui dokumen tersebut, Kementerian Luar Negeri juga menyatakan bahwa diplomasi ekonomi Indonesia bertujuan 
untuk mendukung "quality growth" atau "quality with equity" yang disesuaikan dengan kepentingan Indonesia sebagai negara berkembang.

Dalam dokumen lainnya, Kementerian Luar Negeri juga menyatakan bahwa diplomasi ekonomi diantaranya diupayakan melalui pencarian peluang pasar dan produk (opportunity seeker), memasarkan produk Indonesia (promoting dan marketing), fasilitasi kemitraan (match-making), serta mengupayakan kepentingan nasional dalam forum regional maupun multilateral (Kementerian Luar Negeri, 2015a). Kementerian Luar Negeri juga memiliki "Indeks Diplomasi Ekonomi" sebagai sarana untuk mengukur ketercapaian sasaran strategis diplomasi ekonomi.

Namun demikian, pada dasarnya diplomasi ekonomi tidak menjadi instrumen dan strategi yang secara eksklusif hanya diimplementasikan oleh Kementerian Luar Negeri. Diplomasi ekonomi menjadi agenda besar yang kemudian diterjemahkan oleh kementerian-kementerian melalui berbagai rencana strategis. Dalam konteks diplomasi ekonomi, beberapa lembaga negara yang terlibat secara langsung diantaranya adalah Kementerian Luar Negeri, Perdagangan, Kementerian BUMN, Kementerian Perindustrian, dan Kementerian Keuangan.

Melalui Kementerian Perdagangan, diplomasi ekonomi yang tertuang dalam rencana strategis perdagangan luar negeri periode 2015-2019 dirumuskan ke dalam tiga sasaran utama, yaitu peningkatan pertumbuhan ekspor produk non-migas, peningkatan rasio ekspor jasa terhadap produk domestik bruto (PDB), dan peningkatan pangsa ekspor produk manufaktur (Kementerian Perdagangan Republik Indonesia, 2015). Arah kebijakan perdagangan luar negeri tersebut juga disokong oleh empat pilar strategi, yaitu: 1) menjaga dan meningkatkan pangsa pasar produk Indonesia di pasar ekspor utama (market maintenance), 2) meningkatkan pangsa pasar ekspor di pasar prospektif (market creation), 3) mengidentifikasi peluang pasar ekspor produk dan jasa potensial (product creation), dan 4) meningkatkan fasilitasi 
ekspor dan impor untuk mendukung daya saing produk nasional (export facilitation and import management).

Sementara itu melalui Kementerian Keuangan, beberapa program yang menjadi tindak lanjut diplomasi ekonomi diantaranya adalah pemberian fasilitasi ekspor melalui pembentukan Pusat Penanganan Perizinan Impor Ekspor Terpadu (P3IET) dan pemberian fasilitas Kemudahan Impor Tujuan Ekspor (KITE) (Kementerian Keuangan Republik Indonesia, 2016).

Memasuki tahun 2020 hingga terjadinya pandemi Covid-19, diplomasi ekonomi tetap menjadi fokus politik luar negeri Indonesia yang tergabung dalam prioritas diplomasi " $4+1$ " Kementerian Luar Negeri, yakni penguatan diplomasi ekonomi, diplomasi perlindungan, diplomasi kedaulatan dan kebangsaan, serta peran Indonesia di kawasan dan global (Kementerian Luar Negeri, 2020b). Sementara itu “+1" merujuk pada penguatan infrastruktur diplomasi. Dalam konteks yang lebih luas, diplomasi ekonomi juga ditujukan untuk mewujudkan perdamaian dunia melalui upaya memperkuat paradigma kerjasama dan kolaborasi antara Indonesia dengan negara-negara lain di dunia. Hal ini ditujukan untuk membangun paradigma kolektif yang saling menguntungkan, berkeadilan, dan menghindari skenario "zero-sum" (Delanova, 2020; Rachmahyanti, 2020). Pada periode ini pula, diplomasi ekonomi diperkuat melalui penugasan-penugasan khusus kepada perwakilan Republik Indonesia di luar negeri (Kementerian Luar Negeri, 2020b).

\section{Dampak Pandemi Covid-19 terhadap Kinerja Perekonomian Indonesia}

Seperti yang telah disinggung pada bagian sebelumnya, pandemi Covid-19 menyebabkan pertumbuhan ekonomi Indonesia pada kuartal 2 tahun 2020 mengalami kontraksi sebesar minus 5,3 persen (year on year). Berdasarkan keterangan yang dihimpun dari Kementerian Perdagangan, pandemi Covid-19 telah menyebabkan perubahan pola perdagangan global sebagai imbas terjadinya demand dan supply shock (CNBC Indonesia, 2020). Perubahan pada pusat rantai pasokan global juga terjadi sebagai imbas dari 
krisis yang terjadi di negara-negara pusat perekonomian seperti Tiongkok, Amerika Serikat, dan Jerman.

Bagi Indonesia, kondisi di atas menyebabkan terjadinya defisit pada neraca perdagangan nasional. Bank Indonesia mencatat bahwa hingga bulan April 2020, neraca perdagangan Indonesia defisit hingga US\$ 344,7 juta. Angka ini mayoritas dipengaruhi oleh defisit perdagangan sektor non-migas sebesar US\$ 100,9 juta dan sektor migas sebesar US\$243,8 juta (Hendartyo, 2020). Selain itu, pandemi Covid-19 juga menyebabkan penurunan kinerja ekspor-impor Indonesia. Hingga bulan Mei 2020, ekspor Indonesia mengalami penurunan sebesar 13,4 persen month to month (mtom) dan 28,95 persen year on year (yoy). Sementara itu impor nasional mengalami penurunan dengan kisaran 32,65 persen mtom dan 42,2 persen yoy (Thomas, 2020). Badan Pusat Statistik turut mencatat bahwa beberapa komoditas Indonesia yang paling terdampak pandemi adalah kendaraan dan komponen penyusunnya, timah dan barang olahannya, barang tekstil, mesin dan perlengkapan elektrik, serta pakaian dan aksesoris (rajutan) (Zuhriyah, 2020).

Menyikapi kondisi tersebut, muncul urgensi untuk menerapkan strategi kebijakan ekonomi khusus untuk "menahan" dampak negatif pandemi terhadap perekonomian nasional, termasuk didalamnya melibatkan upaya diplomasi ekonomi. Meskipun demikian, hal ini juga memiliki tantangan mengingat pemberlakuan containment measures secara global membuat perwakilan perdagangan (atase perdagangan), Indonesian Trade Promotion Centre (ITPC), kamar dagang, hingga Kantor Dagang dan Ekonomi Indonesia (KDEI) sulit mengadakan pameran untuk mengumpulkan para buyer dari mancanegara (CNBC Indonesia, 2020).

\section{Diplomasi Ekonomi sebagai Strategi Perbaikan Perekonomian Nasional}

Menghadapi situasi pelemahan perekonomian nasional, penerapan diplomasi ekonomi bersandar pada dua koridor tujuan. Pada koridor politik, diplomasi ekonomi memiliki tujuan untuk menjaga stabilitas dan kinerja 
perekonomian nasional di masa pandemi, serta menjaga konektivitas nasional dengan rantai pasokan global untuk menjaga ketersediaan kebutuhan-kebutuhan yang esensial seperti pangan maupun perlengkapan medis. Diplomasi ekonomi dalam upaya menjaga konektivitas rantai pasokan baik di level regional maupun global juga ditujukan untuk mempercepat pemulihan kondisi pasca pandemi (recovery). Sementara itu, diplomasi dalam ranah ekonomi ditujukan untuk memberikan proteksi pada sektor industri nasional, mendorong peluang ekspor pada kebutuhan-kebutuhan pokok, dan mengurangi cost ekspor.

Secara umum, strategi diplomasi ekonomi Indonesia dalam menghadapi pandemi Covid-19 berdasar pada Peraturan Menteri Perdagangan Republik Indonesia (Permendag) No. 10 Tahun 2020, Peraturan Pemerintah Pengganti Undang-Undang (Perppu) No. 1 Tahun 2020, Keputusan Presiden (Keppres) No. 9 Tahun 2020, serta Keppres No. 11 tahun 2020. Bentuk aktivitas yang dilaksanakan diantaranya adalah melakukan realokasi dan refocusing anggaran, menjaga stabilitas harga dan stok barang kebutuhan pokok dalam negeri, melakukan relaksasi impor peralatan kesehatan, pemberian stimulus ekonomi non-fiskal untuk barang-barang ekspor, melakukan pengawasan barang/jasa yang beredar dalam perdagangan daring, memberikan fasilitasi ekspor, pelatihan bagi eksportir secara virtual, serta pemanfaatan forum kerjasama perdagangan internasional untuk mengupayakan business-matching secara virtual (Kontan, 2020).

Salah satu kunci diplomasi ekonomi Indonesia dalam menghadapi pandemi tampak dalam pemberian fasilitas untuk mendorong kemudahan ekspor produk olahan pangan. Sebagai salah satu komoditas unggulan Indonesia, strategi ini ditujukan untuk memperbaiki perekonomian nasional saat memasuki kuartal 2 tahun 2020 (Elshinta, 2020). Dalam memberikan fasilitasi ekspor, pemerintah melalui Kementerian Perdagangan memberikan stimulus ekonomi non-fiskal berupa penerbitan surat keterangan asal (SKA) 
barang ekspor melalui penerapan affixed signature and stamp. Hal ini ditujukan untuk mempercepat dan mempermudah pelayanan ekspor (Andrianita, 2020d). Stimulus ini juga didukung oleh program Ekosistem Logistik Nasional (NLE) untuk mendorong penerapan autentikasi otomatis perizinan ekspor dan impor bagi pelaku usaha yang telah memiliki reputasi, serta meningkatkan, mempercepat, dan mengawasi layanan ekspor-impor (Andrianita, 2020b).

Selain berfokus pada relaksasi dan pemberian fasilitas ekspor-impor pada produk olahan pangan, diplomasi ekonomi Indonesia turut ditujukan pada ekspor sektor industri garmen (khususnya pakaian pelindung diri dan masker) (Alika, 2020b) serta komoditas minyak kelapa sawit (crude palm oil/CPO) (Alika, 2020a). Ekspor pakaian pelindung diri dan masker didorong dengan memperhatikan ketersediaan di dalam negeri, yakni dengan melakukan pengajuan Persetujuan Ekspor (PE) melalui sistem Indonesian National Single Window (INSW). Sementara itu ekspor CPO (dalam kemasan) didorong ke negara-negara Afrika Timur mengingat fungsi vitalnya sebagai salah satu bahan kebutuhan pokok.

Pemerintah Indonesia melalui Kementerian Luar Negeri juga mendorong diplomasi ekonomi melalui peran strategis perwakilan perdagangan Indonesia di luar negeri. Tujuannya untuk menggali informasi terbaru tentang perkembangan situasi negara tujuan ekspor, serta mendorong promosi ekspor dan business matching secara virtual (Kontan, 2020). Sinergi antara perwakilan perdagangan Indonesia dengan pelaku usaha juga diupayakan agar para eksportir Indonesia tetap dapat mengakses pasar dengan pemahaman regulasi atau ketentuan terbaru di negara-negara tujuan selama masa pandemi. Hal ini diantaranya ditunjukkan dengan peningkatan ekspor kopi ke Mesir, rumput laut ke Korea Selatan, pelaksanaan workshop virtual oleh KJRI Houston, dan promosi TTI (trade, tourism, investment) oleh KBRI Beijing (Kementerian Luar Negeri, 2020a). 
Selain itu, diplomasi ekonomi juga dilakukan dengan memperkuat koordinasi perdagangan multilateral (melalui forum G20) dan regional (ASEAN) (Andrianita, 2020c). Berdasarkan keterangan yang dihimpun dari Direktur Perundingan ASEAN Kementerian Perdagangan, Indonesia mendorong negara-negara anggota untuk terbuka dan transparan dalam kebijakan perdagangan masing-masing. Selain itu, pemerintah Indonesia juga mendorong penyelesaian negosiasi perjanjian (perdagangan) internasional secara daring, diantaranya adalah Indonesia-European Free Trade Association Comprehensive Economic Partnership Agreement (IE-CEPA) dan Indonesia-Australia Comprehensive Economic Partnership Agreement (IA-CEPA) (Andrianita, 2020a).

Terakhir, diplomasi ekonomi Indonesia selama masa pandemi juga dapat dilihat pada kebijakan-kebijakan yang berkaitan dengan aspek fiskal maupun moneter. Pemerintah melalui program Pemulihan Ekonomi Nasional (PEN) yang tertuang dalam Peraturan Pemerintah Nomor 23 Tahun 2020 tentang Pelaksanaan Program Pemulihan Ekonomi Nasional dalam Rangka Mendukung Kebijakan Keuangan Negara untuk Penanganan Pandemi Corona Virus Disease 2019 (Covid-19) dan/atau Menghadapi Ancaman yang membahayakan Perekonomian Nasional dan/atau Stabilitas Sistem Keuangan Serta Penyelamatan Ekonomi Nasional, memberikan stimulus kredit dan permodalan kerja bagi pemulihan sektor industri manufaktur terutama yang berorientasi ekspor (Andrianita, 2020d). Kebijakan ini juga didukung oleh inisiatif Kementerian Perdagangan untuk memberikan asuransi, kredit ekspor, atau pembiayaan lainnya dari sektor perbankan terhadap para eksportir yang terdampak pandemi, serta penandatanganan nota kesepahaman antara Kementerian Luar Negeri dan Bank Indonesia tentang penguatan diplomasi ekonomi (Alaydrus, 2020). 


\section{Analisis dan Identifikasi Diplomasi Ekonomi Indonesia}

Jika dilihat dalam konsep diplomasi ekonomi seperti yang dikemukakan oleh Kostecki dan Naray, diplomasi ekonomi Indonesia dalam menghadapi pandemi Covid-19 dapat dikelompokkan dalam bentuk primary dan support activities. Primary activities merujuk pada perdagangan dan foreign direct investments (FDIs), pengembangan riset dan teknologi, promosi pariwisata serta advokasi bisnis. Sementara itu support activities berkaitan dengan intelijen, pembangunan jaringan, negosiasi bisnis, dan mekanisme penyelesaian permasalahan. Secara ringkas, pengelompokkan aktivitas diplomasi ekonomi Indonesia dapat dilihat pada tabel berikut:

Tabel 1. Diplomasi Ekonomi Pemerintah Indonesia dalam Penanganan Pandemi Covid-19

\begin{tabular}{|c|c|c|}
\hline & Pemerintah Indonesia \\
\hline \multirow[t]{2}{*}{$\begin{array}{l}\text { Primary } \\
\text { Activitie } \\
s\end{array}$} & $\begin{array}{l}\text { Perdagangan } \\
\text { dan } \\
\text { Pemasaran }\end{array}$ & $\begin{array}{l}\text { - Realokasi dan refocusing anggaran } \\
\text { - } \text { emberian stimulus ekonomi non-fiskal } \\
\text { penerbitan surat keterangan asal (SKA) dan } \\
\text { penerapan affixed signature and stamp } \\
\text { - Penerapan program Ekosistem Logistik } \\
\text { Nasional (NLE) untuk mendorong penerapan } \\
\text { autentikasi otomatis perizinan ekspor-impor } \\
\text { - Inisiatif pemberian asuransi, kredit ekspor, } \\
\text { dan pembiayaan lainnya dari sektor } \\
\text { perbankan kepada eksportir } \\
\text { Memberikan relaksasi fasilitasi ekspor bagi } \\
\text { komoditas unggulan melalui sistem } \\
\text { Pengajuan Ekspor (PE) dalam sistem } \\
\text { Indonesian National Single Window (INSW): } \\
\text { - bahan pangan } \\
\text { - garmen (alat pelindung diri dan masker) } \\
\text { - CPO ke negara-negara di Afrika Timur }\end{array}$ \\
\hline & $\begin{array}{l}\text { Advokasi } \\
\text { Bisnis }\end{array}$ & $\begin{array}{l}\text { - } \text { Mendorong peran strategis perwakilan } \\
\text { perdagangan Indonesia di luar negeri untuk }\end{array}$ \\
\hline
\end{tabular}




\begin{tabular}{|c|c|c|}
\hline & & $\begin{array}{l}\text { mendorong promosi ekspor dan business } \\
\text { matching secara virtual }\end{array}$ \\
\hline \multirow{3}{*}{$\begin{array}{l}\text { Support } \\
\text { Activitie } \\
\text { s }\end{array}$} & $\begin{array}{l}\text { Jaringan dan } \\
\text { Negosiasi } \\
\text { Bisnis }\end{array}$ & $\begin{array}{l}\text { - Pemanfaatan kerjasama perdagangan } \\
\text { internasional untuk mengupayakan } \\
\text { business-matching } \\
\text { - Memperkuat koordinasi perdagangan } \\
\text { multilateral melalui forum G20 dan ASEAN } \\
\text { - Penandatanganan nota kesepahaman antara } \\
\text { Kementerian Luar Negeri dengan Bank } \\
\text { Indonesia tentang penguatan diplomasi } \\
\text { ekonomi }\end{array}$ \\
\hline & Intelijen & $\begin{array}{l}\text { - Melakukan pengawasan bawang/jasa yang } \\
\text { beredar dalam perdagangan secara daring } \\
\text { - Menggali informasi tentang situasi dan } \\
\text { perkembangan regulasi negara tujuan ekspor } \\
\text { melalui perwakilan perdagangan Indonesia di } \\
\text { luar negeri } \\
\text { - Peningkatan ekspor kopi ke Mesir } \\
\text { - Peningkatan ekspor rumput laut ke Korea } \\
\text { - Selatan } \\
\text { - Workshop virtual oleh KJRI Houston } \\
\text { Konferensi virtual untuk promosi TTI } \\
\text { (trade, tourism, investment) oleh KBRI } \\
\text { Beijing }\end{array}$ \\
\hline & $\begin{array}{l}\text { Penyelesaian } \\
\text { Permasalahan }\end{array}$ & $\begin{array}{l}\text { - Menjaga stabilitas harga dan stok barang } \\
\text { kebutuhan pokok dalam negeri } \\
\text { - Memberikan pelatihan virtual bagi eksportir } \\
\text { - } \text { perjanjian (perdagangan) internasional, salah } \\
\text { satunya adalah Indonesia-EU CEPA dan } \\
\text { IA-CEPA } \\
\text { - Peluncuran Program Pemulihan Ekonomi } \\
\text { Nasional (PEN) }\end{array}$ \\
\hline
\end{tabular}

Berdasarkan gambaran dan uraian di atas, tampak bahwa kepentingan/tujuan politik pemerintah Indonesia (power play-end) dalam konteks penanganan pandemi Covid-19 yakni menjaga stabilitas dan kinerja 
perekonomian nasional serta menjaga konektivitas nasional dengan rantai pasokan global untuk menjaga ketersediaan kebutuhan-kebutuhan yang esensial. Sementara itu tujuan/kepentingan ekonomi (business-end) yaitu mendorong peluang ekspor pada komoditas kebutuhan pokok dan mengurangi cost ekspor. Kedua tujuan tersebut kemudian diterjemahkan ke dalam berbagai aktivitas diplomasi dalam ranah primary maupun support activities, baik dalam bidang perdagangan dan pemasaran, advokasi bisnis, pembentukan jaringan dan negosiasi bisnis, intelijen, dan upaya penyelesaian permasalahan. Uraian tersebut memberikan gambaran tentang strategi diplomasi ekonomi Indonesia dalam menghadapi pandemi Covid-19.

\section{KESIMPULAN}

Dalam menghadapi dampak negatif pandemi Covid-19 terhadap perekonomian nasional Indonesia, pemerintah Indonesia melalui Kementerian Perdagangan, Kementerian Luar Negeri, Kementerian Perindustrian, Kementerian Perdagangan, bersama lembaga negara lainnya termasuk Bank Indonesia mengupayakan perubahan strategi diplomasi ekonomi nasional. Perubahan strategi diplomasi ekonomi ini secara hukum berlandaskan pada ketentuan yang termuat dalam Peraturan Menteri Perdagangan Republik Indonesia (Permendag) No. 10 Tahun 2020, Peraturan Pemerintah Pengganti Undang-Undang (Perppu) No. 1 Tahun 2020, Keputusan Presiden (Keppres) No. 9 Tahun 2020, serta Keppres No. 11 tahun 2020.

Melalui analisis dalam kacamata diplomasi ekonomi seperti yang dikonsepsikan Kostecki dan Naray, strategi diplomasi ekonomi Indonesia dalam menghadapi pandemi Covid-19 dapat dipahami dan dijelaskan dalam deskripsi aktivitas primary maupun support yang dilakukan oleh pemerintah Indonesia selama masa pandemi. Melalui kerangka konseptual tersebut, tujuan dan bentuk diplomasi ekonomi Indonesia dalam menghadapi dampak pandemi juga dapat dijelaskan dan diidentifikasi secara rinci. 
Secara politik, diplomasi ekonomi oleh pemerintah Indonesia bertujuan untuk menjaga stabilitas dan kinerja perekonomian nasional di masa pandemi, menjaga konektivitas nasional dengan rantai pasokan global untuk menjaga ketersediaan kebutuhan-kebutuhan yang esensial seperti pangan maupun perlengkapan medis, hingga mempercepat pemulihan kondisi pasca pandemi (recovery). Sementara itu secara ekonomi, diplomasi ekonomi ditujukan untuk memberikan proteksi pada sektor industri nasional, mendorong peluang ekspor pada kebutuhan-kebutuhan pokok, dan mengurangi biaya ekspor.

Aktivitas diplomasi ekonomi Indonesia dalam menghadapi pandemi Covid-19 secara keseluruhan meliputi realokasi dan refocusing anggaran, upaya menjaga stabilitas harga dan stok barang kebutuhan pokok dalam negeri, melakukan relaksasi impor peralatan kesehatan, pemberian stimulus ekonomi non-fiskal untuk barang-barang ekspor, melakukan pengawasan barang/jasa yang beredar dalam perdagangan daring, memberikan fasilitasi ekspor, melakukan business-matching secara daring melalui Konsulat Jenderal Republik Indonesia (KJRI) di luar negeri, serta pemanfaatan forum (perdagangan) regional maupun multilateral. Aktivitas diplomasi yang dilakukan meliputi primary activities dalam aspek perdagangan dan pemasaran serta advokasi bisnis, serta support activities pada aspek pembangunan jaringan dan negosiasi bisnis, intelijen, dan mekanisme penyelesaian permasalahan. 


\section{REFERENSI}

Alaydrus, H. (2020) Gubernur BI dan Menlu Perkuat Kerja Sama Diplomasi

Ekonomi di Masa Covid-19, Bisnis.com. Available at:

https://ekonomi.bisnis.com/read/20200520/9/1243086/gubernur-bi-d an-menlu-perkuat-kerja-sama-diplomasi-ekonomi-di-masa-covid-19 (Accessed: 14 June 2020).

Aleidan, M. (2019) 'Commercial diplomacy as a part of national transformation and its impact on the internationalization of SMEs: Evidence from Saudi Arabia', Asian Economic and Financial Review, 9(9), pp. 1019-1031. doi: 10.18488/journal.aefr.2019.99.1019.1031.

Alika, R. (2020a) Di Tengah Pandemi, Pengusaha Lirik Ekspor CPO Kemasan ke Afrika Timur, Katadata. Available at:

https://katadata.co.id/berita/2020/06/16/di-tengah-pandemi-pengusa ha-lirik-ekspor-cpo-kemasan-ke-afrika-timur (Accessed: 14 June 2020).

Alika, R. (2020b) Dorong Aktivitas Ekonomi, Mendag Buka Keran Ekspor APD dan Masker, Katadata. Available at:

https://katadata.co.id/berita/2020/06/16/dorong-aktivitas-ekonomi-m endag-buka-keran-ekspor-apd-dan-masker (Accessed: 14 June 2020).

Amanta, F. and Aprilianti, I. (2020) Kebijakan Perdagangan Pangan Indonesia. Jakarta.

Andrianita, O. (2020a) Dorong Implementasi IA-CEPA, Kemendag Fasilitasi Penandatanganan Kerja Sama Perusahaan Australia dengan Eksportir Indonesia, Kementerian Perdagangan. Jakarta. doi: 10.1111/1540-5885.1110069.

Andrianita, O. (2020b) Lawan COVID-19: Kementerian Perdagangan Lakukan Realokasi dan Refokusing Anggaran Tahun 2020. Jakarta.

Andrianita, O. (2020c) Lawan COVID-19: Menteri Perdagangan G20 Sepakati 
Aksi G2O untuk Mendukung Perdagangan dan Investasi Dunia. Jakarta.

Andrianita, O. (2020d) Lawan COVID-19: Perkuat Ekspor, Kemendag Fasilitasi Ekspor dengan Terbitkan Permendag Nomor 39 Tahun 2020. Jakarta.

Budiyanti, E. (2020) 'Dampak Virus Corona terhadap Sektor Perdagangan dan Pariwisata Indonesia', Kajian Singkat Terhadap Isu Aktual dan Strategis, Pusat Penelitian Badan Keahlian DPR RI, 12(4).

CNBC Indonesia (2020) Wamendag Buka-bukaan Soal Perdagangan RI di Era Covid-19, CNBC Indonesia.

Curzon, G. (1965) 'Multilateral Commercial Diplomacy', in The General Agreement on Tariffs and Trade and its Impact on National Commercial Policies and Techniques, p. 367.

Damuri, Y. R. and Hirawan, F. B. (2020) 'Mengukur Dampak COVID-19 pada Pertumbuhan Ekonomi dan Perdagangan Indonesia 2020', CSIS Commentaries, (March).

Delanova, M. (2016) 'Diplomasi Ekonomi Indonesia dan Negara-negara Berkembang dalam G-33 untuk Mempromosikan Proposal Special Products dan Special Safeguard Mechanism', Dinamika Global, 01(1), pp. $14-31$.

Delanova, M. O. (2020) 'Analisis Kebijakan Diplomasi Ekonomi Indonesia Terhadap Pasar Non Tradisional', Jurnal Dinamika Global, 4(02), pp. 382-402. doi: 10.36859/jdg.v4i02.140.

Djelantik, S. (2020) Kerjasama Global Menangani The "Great Lockdown"; Pendekatan Diplomasi Multijalur. Bandung.

Elshinta (2020) Kemendag dongkrak ekspor pangan olahan, Elshinta. Available at: https://elshinta.com/news/208762/2020/06/16/kemendag-dongkrak- 
ekspor-pangan-olahan (Accessed: 14 June 2020).

Falahi, Z. and Nainggolan, P. P. (2020) 'Regionalisme ASEAN dalam Merespons Pandemik Covid-19', Kajian Singkat Terhadap Isu Aktual dan Strategis, Pusat Penelitian Badan Keahlian DPR RI, 12(7).

Hendartyo, M. (2020) Pandemi Covid-19 Bikin Neraca Perdagangan Indonesia Defisit, Tempo.co. Available at:

https:/ / bisnis.tempo.co/read/1342879/pandemi-covid-19-bikin-neracaperdagangan-indonesia-defisit (Accessed: 14 June 2020).

International Monetary Fund (2020a) Policy Responses To Covid-19: Policy Tracker. Available at:

https://www.imf.org/en/Topics/imf-and-covid19/Policy-Responses-to-C OVID-19\#J (Accessed: 23 May 2020).

International Monetary Fund (2020b) World Economic Outlook (Chapter 1: The Great Lockdown). Available at: https:// blogs.imf.org/2019/07/23/sluggish-global-growth-calls-for-sup portive-policies/.

Kembara, G. (2020) 'A New Footing: Finding Indonesia's Post-COVID-19 Strategic Focus', CSIS Commentaries, pp. 1-4.

Kementerian Keuangan Republik Indonesia (2016) Laporan Kinerja Kementerian Keuangan Tahun 2016, Kementerian Keuangan. Jakarta. doi: $10.1017 /$ CBO9781107415324.004.

Kementerian Luar Negeri (2015a) Diplomasi Ekonomi Kementerian Luar Negeri RI, Kementerian Luar Negeri. Available at: https://diplomasiekonomi.kemlu.go.id/index.php/beranda (Accessed: 27 April 2020).

Kementerian Luar Negeri (2015b) Rencana Strategis Kementerian Luar Negeri Republik Indonesia 2015-2019. Jakarta. Available at: 
http://www.kemlu.go.id/AKIP/Rencana Strategis Kemlu 2015-2019.pdf.

Kementerian Luar Negeri (2020a) Pandemi COVID-19 Tak Surutkan KJRI Houston Untuk Lanjutkan Diplomasi Ekonomi, Kementerian Luar Negeri Republik Indonesia. Available at:

https:// kemlu.go.id/portal/id/read/1183/berita/pandemi-covid-19-taksurutkan-kjri-houston-untuk-lanjutkan-diplomasi-ekonomi (Accessed: 15 June 2020).

Kementerian Luar Negeri (2020b) Pernyataan Pers Tahunan Menteri Luar Negeri RI 2020: Prioritas Diplomasi 4+1, Kementerian Luar Negeri Republik Indonesia. Available at: https://kemlu.go.id/ankara/id/news/4152/pernyataan-pers-tahunanmenteri-luar-negeri-ri-2020-prioritas-diplomasi-41-diplomacy4peaceand prosperity\#: :text=Selanjutnya\%2C Menlu Retno menyampaikan prioritas,Indonesia di kawasan dan global. (Accessed: 13 June 2020).

Kementerian Perdagangan Republik Indonesia (2015) Rencana Strategis Kementerian Perdagangan Tahun 2015-2019. Jakarta: Kementerian Perdagangan Republik Indonesia. doi: 351.077 Ind r.

Killian, P. M. E. (2012) 'Paradigma dan Problematika Diplomasi Ekonomi Indonesia', Global \& Strategis, (2), pp. 170-185.

Klinkby, B. I. (2013) 'Minister Meetings-A Commercial Diplomacy Approach for Small Open States How Danish Minister Meetings can Foster Business Opportunities in China', (May), pp. 1-86. Available at: http://studenttheses.cbs.dk/xmlui/bitstream/handle/10417/4155/bjoe rg_ilsoe_klinkby.pdf?sequence $=1$.

Kontan (2020) Mendag Jalankan Langkah Strategis Bidang Perdagangan di Masa Pandemi Covid-19, Kontan. Available at: https:// pressrelease.kontan.co.id/release/mendag-jalankan-langkah-str ategis-bidang-perdagangan-di-masa-pandemi-covid-19 (Accessed: 14 
June 2020).

Kopp, H. W. (2004) Commercial Diplomacy and the National Interest. American Academy of Diplomacy.

Kostecki, M. and Naray, O. (2007) 'Commercial Diplomacy and International Business', Netherlands Institute of International Relations 'Clingendael', pp. vix-xix. doi: 10.1108/S1877-6361(2012)0000009004.

Kurniawan, A. (2014) 'Diplomasi Ekonomi Indonesia dan Thailand terhadap Pasar Timur Tengah', Jurnal Ilmu Sosial dan Ilmu Politik, 17(3), pp. 254-271.

Mantong, A. W. and Kharisma, M. W. (2020) Event Report: Indonesia-Korea Cooperation in Dealing with Covid-19. Jakarta.

Martha, J. (2020) Pemanfaatan Diplomasi Publik oleh Indonesia dalam Krisis Covid-19. Bandung.

Naray, O. and Bezençon, V. (2017) 'Management and Business Research on Commercial Diplomacy: Examining Trends and Themes', International Trade Journal. Routledge, 31(4), pp. 332-359. doi:

10.1080/08853908.2017.1291379.

Okano-Heijmans, M. (2011) 'Conceptualizing Economic Diplomacy: The Crossroads of International Relations, Economics, IPE and Diplomatic Studies', in Bergeijk, P. A. G. van, Okano-Heijmans, M., and Melissen, J. (eds) Economic Diplomacy: Economic and Political Perspectives. London: Martinus Nijhoff.

Rachmahyanti, S. (2020) Menlu Retno: 2020, Indonesia Perkuat Diplomasi Ekonomi, Warta Ekonomi. Available at: https://www.wartaekonomi.co.id/read265518/menlu-retno-2020-indon esia-perkuat-diplomasi-ekonomi (Accessed: 14 June 2020). 
Reuvers, S. and Ruël, H. (2012) Research on Commercial Diplomacy: A Review and Implications. University of Twente. doi: 10.1108/s1877-6361(2012)0000009005.

Sabaruddin, S. S. (2015) Penguatan Diplomasi Ekonomi Indonesia Mendesain Clustering Tujuan Pasar Ekspor Indonesia: Pasar Tradisional us Pasar Non-Tradisional.

Sabaruddin, S. S. (2017) Grand Design Diplomasi Ekonomi Indonesia: Sebuah Pendekatan Indeks Diplomasi Ekonomi.

Stadman, A. and Ruël, H. (2012) 'Competitors or Collaborators: A Comparison of Commercial Diplomacy Policies and Practices of EU Member States', in Commercial Diplomacy and International Business: A Conceptual and Empirical Exploration, pp. 183-225.

Strange, S. (1992) 'States , Firms and Diplomacy', International Affairs, 68(1), pp. 1-15.

Tahir, D. S. (2020) 'Stimulus COVID-19', CSIS Commentaries, pp. 6-9.

Thomas, V. F. (2020) Babak Belur Ekspor \& Impor Indonesia di Tengah Pandemi COVID-19, Tirto.id.

Ulya, F. N. (2020) Pertumbuhan Ekonomi RI Minus 5,32 Persen pada Kuartal II-2020, Kompas.com. Available at: https://money.kompas.com/read/2020/08/05/120854826/pertumbuh an-ekonomi-ri-minus-532-persen-pada-kuartal-ii-2020 (Accessed: 8 August 2020).

Veenstra, M. E. H. Van, Yakop, M. and Bergeijk, P. a G. Van (2010) 'Economic Diplomacy, the Level of Development and Trade', Discussion Papers in Diplomacy, pp. 1-31. Available at: http://www.clingendael.nl/sites/default/files/20101000_cdsp_artikel_ van Veenstra, Yakop and van Bergeijk.pdf. 
Wangke, H., Pujayanti, A. and Lisbet (2015) Tantangan dan Peluang Diplomasi Ekonomi Presiden Joko Widodo. Jakarta: P3DI Setjen DPR RI.

World Bank Group (2020) Global Economic Prospects, The World Bank. Washington: The World Bank. doi: 10.2307/j.ctt183pb3w.5.

World Health Organization (2020) WHO Coronavirus Disease (COVID-19) Dashboard, World Health Organization. Available at: https:// covid19.who.int/ (Accessed: 24 May 2020).

Zuhriyah, D. A. (2020) Ini 5 Komoditas Ekspor yang Tertekan di Masa Pandemi Covid-19 Maret 2020, Bisnis.com. 